\title{
Two new wedge-shaped beetles in Albo-Cenomanian ambers of France (Coleoptera: Ripiphoridae: Ripiphorinae)
}

\author{
VINCENT PERRICHOT ${ }^{1}$, ANDRÉ NEL $^{2 *}$ and DIDIER NÉRAUDEAU ${ }^{1}$ \\ ${ }^{1}$ Géosciences Rennes and CNRS UMR 6118, Université Rennes 1, bât. 15, 263, avenue du Général Leclerc, 35042 Rennes Cedex, \\ France; e-mails: Vincent.Perrichot@univ-rennes1.fr, Didier.Neraudeau@univ-rennes1.fr \\ ${ }^{2}$ Entomologie and CNRS UMR 5143, Muséum National d'Histoire Naturelle, 45, rue Buffon, F-75005, Paris, France; \\ e-mail: anel@mnhn.fr
}

Key words. Coleoptera, Ripiphoridae, Ripiphorinae, new genus, new species, amber fossil, Albian, Cenomanian, Archingeay, Salignac, France

\begin{abstract}
Paleoripiphorus deploegi gen. n., sp. n. and Macrosiagon ebboi sp. n., described from two French Albo-Cenomanian ambers (mid Cretaceous), are the oldest definitely identified representatives of the Ripiphoridae: Ripiphorinae. They belong to or are closely related to extant genera of this coleopteran subfamily. Together with Myodites burmiticus Cockerell, 1917 from the Albian Burmese amber, they demonstrate that the group is distinctly older than suggested by the hitherto available fossil record. By inference after the biology of the extant Ripiphorinae, Macrosiagon ebboi may have been parasitic on wasps and Paleoripiphorus deploegi on bees, suggesting that Apoidea may have been present in the Lower Cretaceous.
\end{abstract}

\section{INTRODUCTION}

The Ripiphoridae is a small family of parasitic beetles rather poorly represented in the fossil record, mainly by species from the Eocene Baltic amber (Spahr, 1981) and the Paleogene of Florissant (Colorado, USA) (Scudder, 1890; Meyer, 2003). Only one species is recorded from the Cretaceous Burmese amber. The known fossil species were described in the $19^{\text {th }}$ century or at the beginning of the $20^{\text {th }}$ century and need revisions (see the list of fossil taxa in appendix below). We regard the present study of two Albo-Cenomanian specimens of great importance to estimate the age of this family.

\section{MATERIAL AND METHODS}

The specimens studied here were discovered in two distinct French ambers. The first one in the Albian amber of Archingeay/Les-Nouillers, SW France (Néraudeau et al., 2002), and the second one in the Cenomanian amber of Salignac, near Sisteron, SE France (Fig. 1). The latter is the first fossil inclusion described from this amber deposit.

The Albian amber of Archingeay is honey-coloured to clear brown and rather dusty, whereas the Cenomanian amber of Salignac is dark red-coloured. It was thus impossible to study these inclusions without preparing the specimens. First, the surrounding amber was removed in order to get as close as possible to the inclusions. This operation and the separation of the associated inclusions were carried out under a stereomicroscope using shaving blades transformed into a micro-saw. Then, each specimen was fixed on the head of a pin and mounted in Canada balsam on a rotary mechanism, which allows an easier view of all sides of the specimen during its study (Fig. 2). This new method of exam was created by Gaël de Ploëg.

\section{FAMILY RIPIPHORIDAE}

\section{Subfamily Ripiphorinae}

Genus Paleoripiphorus gen. n.

Type species. Paleoripiphorus deploegi sp. n.

Diagnosis. Very close to the modern genus Ripiphorus, the only visible difference being the presence of only ten antennal segments, instead of eleven (seven biflabellate antennomeres instead of eight).

Etymology. After "paleo" and the extant genus Ripiphorus.

\section{Paleoripiphorus deploegi sp. $\mathrm{n}$.}

(Figs 3-5)

Diagnosis. That of the genus.

Description. Head partly hidden under thorax; length $0.48 \mathrm{~mm}$, width $0.56 \mathrm{~mm}$, not sharply constricted at neck; antennae inserted in front of eyes, $0.96 \mathrm{~mm}$ long, strongly flabellate, with two basal simple segments, seven biflabellate segments and one apical uniflabellate segment; antennal expansions $0.28 \mathrm{~mm}$ long and $0.12 \mathrm{~mm}$ wide; eyes very large, nearly meeting on dorsal side of head and strongly extended but not contiguous on ventral side of head; without small group of ommatidia along posterior margin of eye; mouth-parts not visible, except for the apices of labial palps.

Pronotum $0.48 \mathrm{~mm}$ long, $0.8 \mathrm{~mm}$ wide, general shape trapezoidal, lateral margins rounded, anterior angles smooth; posterior angles weakly protruding posteriorly; median crest on disk apparently absent; ventral structures of thorax poorly visible.

Legs. Procoxae $0.24 \mathrm{~mm}$ long, trochanter $0.16 \mathrm{~mm}$ long, femur $0.44 \mathrm{~mm}$ long, $0.12 \mathrm{~mm}$ wide, tibia $0.56 \mathrm{~mm}$ long, $0.08 \mathrm{~mm}$ wide, first tarsal segment $0.10 \mathrm{~mm}$ long,

\footnotetext{
* Corresponding author.
} 


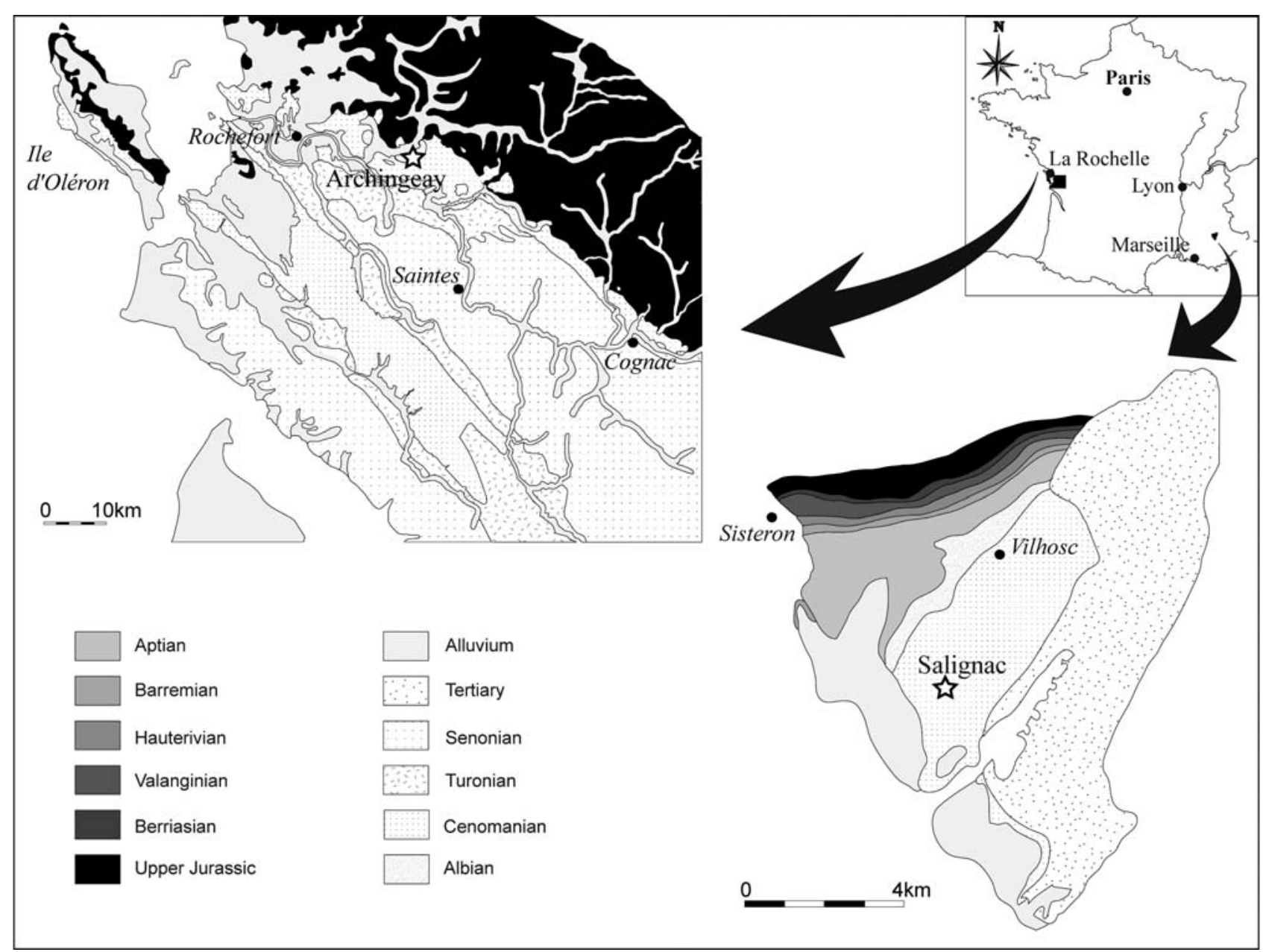

Fig. 1. Location of the studied amber localities (modified from Waterlot \& Polvèche, 1958; Haug et al., 1964).

second $0.09 \mathrm{~mm}$ long, third $0.07 \mathrm{~mm}$ long, fourth 0.07 $\mathrm{mm}$ long, fifth $0.09 \mathrm{~mm}$ long; mesocoxae $0.28 \mathrm{~mm}$ long, $0.16 \mathrm{~mm}$ wide, trochanter $0.16 \mathrm{~mm}$ long, $0.08 \mathrm{~mm}$ wide, femur $0.48 \mathrm{~mm}$ long, $0.16 \mathrm{~mm}$ wide, tibia $0.6 \mathrm{~mm}$ long, $0.08 \mathrm{~mm}$ wide, first tarsal segment $0.10 \mathrm{~mm}$ long, second $0.07 \mathrm{~mm}$ long, third $0.07 \mathrm{~mm}$ long, fourth $0.04 \mathrm{~mm}$ long, fifth $0.07 \mathrm{~mm}$ long; metacoxae $0.28 \mathrm{~mm}$ long, trochanter $0.2 \mathrm{~mm}$ long, $0.08 \mathrm{~mm}$ wide, femur $0.52 \mathrm{~mm}$ long, 0.16 $\mathrm{mm}$ wide, tibia $0.68 \mathrm{~mm}$ long, $0.08 \mathrm{~mm}$ wide, first tarsal segment $0.12 \mathrm{~mm}$ long, second $0.06 \mathrm{~mm}$ long, third 0.06 $\mathrm{mm}$ long, fourth $0.09 \mathrm{~mm}$ long; tarsal claws serrate but without lobiform appendages; tarsal formula 5-5-4; tarsal segments all similar, simple; tibial spurs very small and simple.

Elytra very short, $0.72 \mathrm{~mm}$ long, $0.24 \mathrm{~mm}$ wide; well separated, punctured, with rounded apex just reaching base of abdomen.

Hind wing $1.6 \mathrm{~mm}$ long, about $0.6 \mathrm{~mm}$ wide, wing venation reduced, with no closed cell, only veins $\mathrm{R} 1, \mathrm{M}$, and two posterior veins (maybe $\mathrm{Cu} 1$ and $\mathrm{Cu} 2$ ) visible as more or less straight simple veins; anal area more or less sclerotized; vein $\mathrm{M}$ only sclerotized in its median part but not basally.

Abdomen $1.28 \mathrm{~mm}$ long, $0.76 \mathrm{~mm}$ wide, elongate, with eight segments and apex of ninth segment visible; apical parts of genital appendages partly visible but useless for description.

Holotype. Specimen ARC 254.6, in the same piece of amber with one Ceratopogonidae (Diptera), two small hymenopterans, one larva of Blattodea, the leg of another blattodean, one beetle, and two mites. Deposited in the Laboratoire de Paléontologie, Muséum National d'Histoire Naturelle, Paris, France.

Type locality. Archingeay/Les Nouillers, Charente-Maritime, SW France.

Horizon and age. Lower Cretaceous, Uppermost Albian (Néraudeau et al., 2002).

Etymology. Dedicated to our friend and colleague Mr. Gaël de Ploëg, who found and prepared the studied specimen.

Remarks. Paleoripiphorus gen. n. can be attributed to the Ripiphoridae on the basis of the following characters: tarsal formula 5-5-4, tarsal claws serrate, tibial spur simple, elytra partly reduced, antenna strongly biflabellate (Crowson, 1967). The classification of the family is based on rather old works of Linsley et al. (1952), Besuchet (1956), and Selander (1957). Paleoripiphorus gen. n. shares with the Ripiphorinae: Ripiphorini the following currently used tribal characters: antennae inserted immediately above the eyes, and strongly biflabellate, with only the two basal segments of antenna simple; eyes entire and oval; elytra well separated and very small; hindwing venation reduced, represented by thickened 


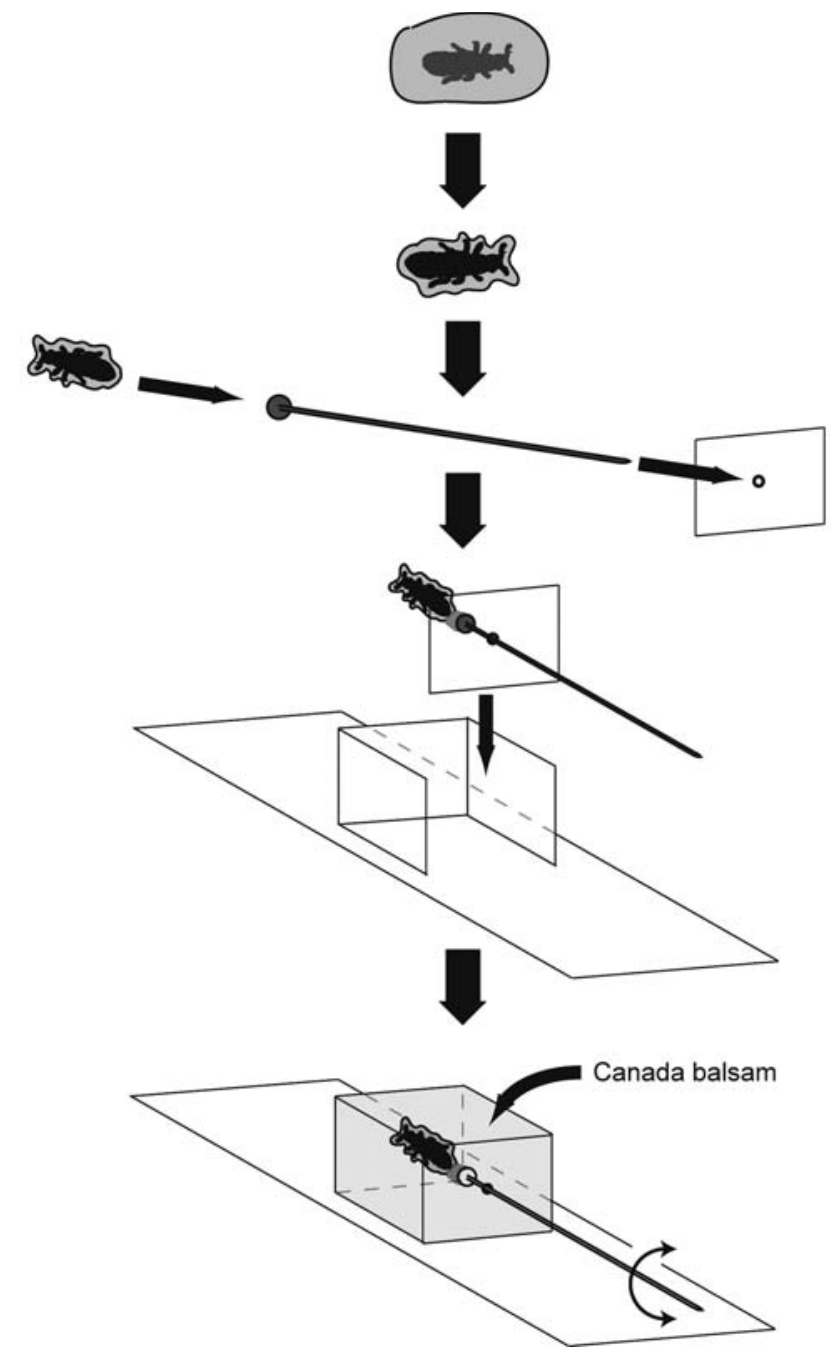

Fig. 2. Preparation of inclusions in amber for study.

streaks, with only veins $\mathrm{R}, \mathrm{M}$ and $\mathrm{Cu}$ still present and no cells in hind wing. Although no phylogenetic analysis of the family is available, some features such as the biflabellate antennae, the very reduced hindwing venation and the very short elytra, can be considered as synapomorphies with other Ripiphorini. Therefore, they strongly support the placement of Paleoripiphorus gen. n. in this tribe.

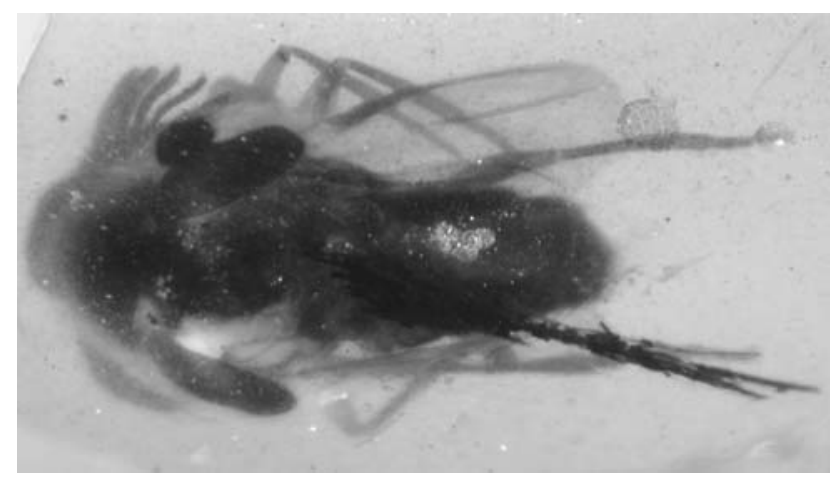

Fig. 3. Paleoripiphorus deploegi gen. n., sp. n., holotype ARC 254.6, photograph of dorsal view.
Paleoripiphorus gen. n. differs from Ripiphorus Bosc, 1792, unique extant Ripiphorini, in the following character: antenna with only seven biflabellate segments, instead of eight biflabellate segments in male Ripiphorus, or ten uniflabellate or simple segments in female Ripiphorus (Rivnay, 1929).

Modern Ripiphorus spp. appear to be strictly parasitic on bees (Selander, 1957; Lawrence \& Britton, 1991; Falin et al., 2000). By inference it appears plausible to assume that Paleoripiphorus gen. n. was probably parasitic on "ancestral" bees. The oldest known bee appears later during the Turonian, but it belongs to a very advanced lineage in the bee family Apidae (Engel, 2000). Thus the present discovery of Paleoripiphorus gen. n. in the French Lower Cretaceous amber supports the hypothesis of the presence of the Apoidea during the Albian. Furthermore the presence of the very advanced subfamily Ripiphorinae in the Albian supports the hypothesis of appearance of the Ripiphoridae during the Lower Cretaceous or the Upper Jurassic.

\section{Genus Macrosiagon Hentz, 1830 \\ Macrosiagon ebboi sp. $\mathbf{n}$. \\ (Fig. 6)}

Diagnosis. Body black, about $5 \mathrm{~mm}$ long; posterior angles of pronotum sharp and strongly protruding posteriorly; elytra long, covering three quarters of the abdomen; legs long and slender; one tibial spur on protibia and two long spurs on meso- and metatibiae.

Description. Body black; head almost completely destroyed and useless for description; mouth parts, eyes, frons and insertion of antennae not visible; only one antenna almost completely preserved, $1.7 \mathrm{~mm}$ long, strongly flabellate, with two basal simple segments, eight biflabellate segments and one apical uniflabellate segment; antennal expansions $0.79 \mathrm{~mm}$ long and 0.057 mm wide.

Pronotum $1.7 \mathrm{~mm}$ long, $1.3 \mathrm{~mm}$ wide. General shape trapezoidal, lateral margins rounded, anterior angles smooth; posterior angles sharp and strongly protruding posteriorly, $0.4 \mathrm{~mm}$ long; apparently without median crest on disk; ventral structures of thorax poorly visible.

Legs. Protibia about $0.85 \mathrm{~mm}$ long, first tarsal segment $0.51 \mathrm{~mm}$ long, second $0.22 \mathrm{~mm}$, third to fifth $0.17 \mathrm{~mm}$ long; mesotibia about $1.13 \mathrm{~mm}$ long, first tarsal segment

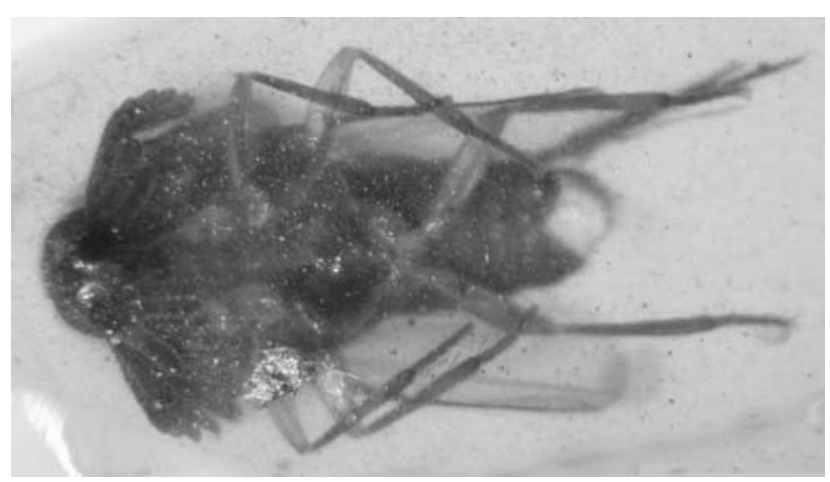

Fig. 4. Paleoripiphorus deploegi gen. n., sp. n., holotype ARC 254.6, photograph of ventral view. 


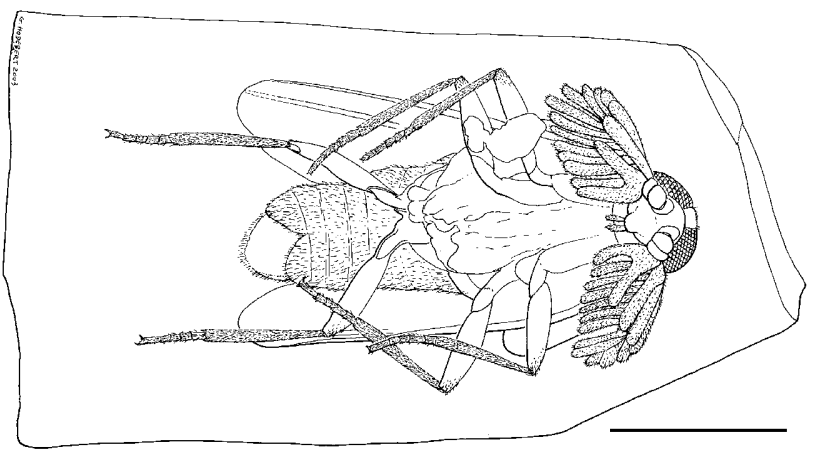

Fig. 5. Paleoripiphorus deploegi gen. n., sp. n., holotype ARC 254.6, ventral view, scale bar represents $1 \mathrm{~mm}$.

$0.51 \mathrm{~mm}$ long, second $0.22 \mathrm{~mm}$ long, third $0.17 \mathrm{~mm}$ long, fourth $0.17 \mathrm{~mm}$ long, fifth $0.17 \mathrm{~mm}$ long; metafemur 1.98 $\mathrm{mm}$ long, $0.56 \mathrm{~mm}$ wide, tibia $2.15 \mathrm{~mm}$ long, $0.11 \mathrm{~mm}$ wide, first tarsal segment $1.076 \mathrm{~mm}$ long, second 0.68 $\mathrm{mm}$ long, third $0.56 \mathrm{~mm}$ long, fourth $0.45 \mathrm{~mm}$ long; tarsal claws long, serrate, without lobiform appendages; tarsal formula 5-5-4; tarsal segments simple; two short spurs at apex of all tarsal segments; protibia with one spur; mesoand metatibia with two very long and simple spurs, mesotibial spurs $0.22 \mathrm{~mm}$ long, metatibial spurs $0.34 \mathrm{~mm}$ long.

Only one elytra preserved, covering three quarters of the abdomen, $3.85 \mathrm{~mm}$ long, $0.9 \mathrm{~mm}$ wide; strongly acuminate and probably dehiscent, punctured.

Hindwing $3.96 \mathrm{~mm}$ long, partly covered by the elytra, but wing venation apparently very reduced without closed cell, only veins R1 and $M$ visible as more or less straight simple veins.

Abdomen $4.25 \mathrm{~mm}$ long, elongate, eight segments and apex of ninth segment visible.

Holotype. Specimen Sis 2.1, deposited in the Laboratoire de Paléontologie, Muséum National d'Histoire Naturelle, Paris, France.

Type locality. Salignac, near Sisteron, Alpes-de-HauteProvence, France.

Horizon and age. The amber was discovered in a marine deposit of blue marls. Although the precise dating remains uncertain, it is assumed of Cenomanian age after the geological map of the area (Haug et al., 1964) (Fig. 1).

Etymology. Dedicated to Mr. Luc Ebbo, who discovered the outcrop of Salignac and gave us the piece of amber with the insect.

Remarks. Macrosiagon ebboi sp. n. can be classified in the Ripiphoridae: Ripiphorinae on the basis of the following characters: tarsal formula 5-5-4; tarsal claws serrate; tibial spur simple; antenna strongly biflabellate, with only the two basal segments simple; hindwing venation reduced. The elytra well developed and clearly acuminate, the long tibial spurs and the sharp posterior angles of the pronotum are characters of the Macrosiagonini. The two extant genera of this tribe, Macrosiagon Hentz, 1830 and Metoecus Gerstaecker, 1855 can be distinguished on the basis of the shape of their occiput (Gressitt, 1941), which is destroyed in M. ebboi sp. n., but also on the basis of the presence of a tibial spur on protibiae and two long spurs on meso- and metatibiae in

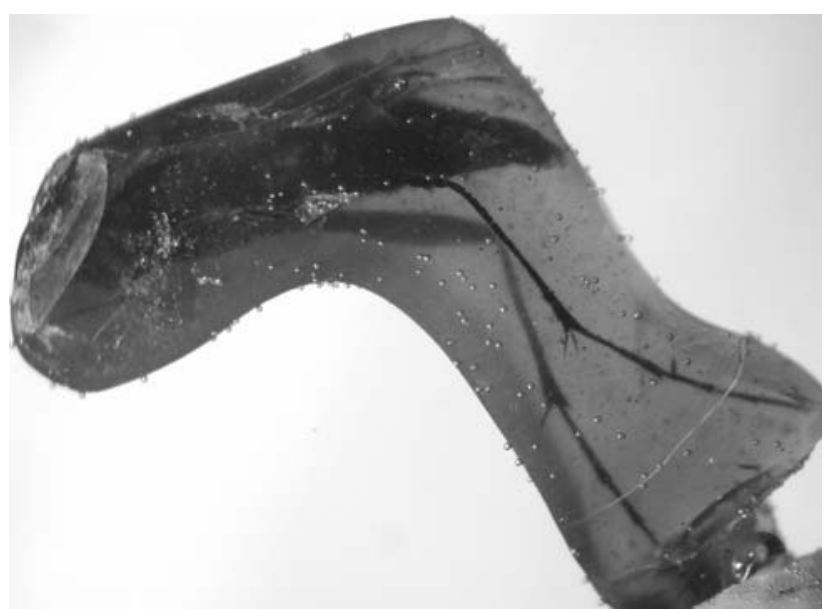

Fig. 6. Macrosiagon ebboi sp. n., holotype Sis 2.1, photograph of lateral view.

Macrosiagon and M. ebboi sp. n., unlike Metoecus. Thus we provisionally attribute the present specimen to the genus Macrosiagon, because there is no known argument to separate them.

Modern Ripiphorinae: Macrosiagonini live on wasps but also on bees (Selander, 1957; Lawrence \& Britton, 1991; Falin et al., 2000). By inference it appears plausible to assume that Macrosiagon ebboi sp. n. was probably parasitic on wasps or bees.

ACKNOWLEDGEMENTS. The authors are greatly indebted to Mr. Marchand, owner of the quarry of Archingeay where the Albian amber was discovered, and L. Ebbo who discovered the outcrop of Salignac, for their helpful contributions in the excavation of the material. We also want to acknowledge G. de Ploëg for his contribution to the field investigations and for the fine preparation of both specimens. We also thank G. Hodebert (MNHN) for drawing and mounting of figures. This paper is a contribution to the "ECLIPSE" CNRS program "Interactions Climat/Ecosystèmes entre l'Aptien et le Paléocène".

\section{REFERENCES}

Besuchet C. 1956: Biologie, morphologie et systématique des Rhipidus (Coleoptera: Rhipiphoridae). Bull. Soc. Entomol. Suisse 29(2): 73-144.

Cockerell T.D.A. 1917: Fossil insects. Appendix. Ann. Entomol. Soc. Am. 10: 19-22.

Crowson R.A. 1967: The Natural Classification of the Families of Coleoptera. Classey, Oxford, Middelsex, UK, $214 \mathrm{pp}$.

Cruickshank R.D. \& Ko Ko 2003: Geology of an amber locality in the Hukawng Valley, Northern Myanmar. J. Asian Earth Sci. 21: 441-455.

Dalman J.W. 1826: Om Insekten inneslutne i copal; jemte beskrifning på några deribland förekommande nya slägten och arter. Kongliga Svenska VetenskAkad. Handl. 1825[1826]: 375-410 (in Swedish).

ENGEL M.S. 2000: A new interpretation of the oldest fossil bee (Hymenoptera: Apidae). Am. Mus. Novit. 3296: 1-11.

FAlin Z.H., Arneson L.C. \& WCisLo W.T. 2000. Night-flying sweat bees Megalopta genalis and Me. Ecuadoria (Hymenoptera: Halictidae) as hosts of the parasitoid beetle Macrosiagon gracilis (Coleoptera: Rhipiphoridae). J. Kansas Entomol. Soc. 73: $183-185$.

GressitT L.J. 1941: Rhipiphoridae from South China (Coleoptera). Ann. Entomol. Soc. Am. 34: 525-536. 
Haug E., Kilian W., Bertrand L., Zürcher P., Martin D., Gubler Y., de Lapparent A.F., Goguel J., Lanteaume M. \& LemorNe M. 1964: Carte géologique au 1/80000e: Digne, $n^{\circ}$ 212 (3ème édition).

Hieke F. \& Pietrzeniuk E. 1984: Die Bernstein-Käfer des Museums für Naturkunde, Berlin (Insecta: Coleoptera). Mitt. Zool. Mus., Berlin 60: 297-326.

Kaupp A., Falin Z. \& Nagel P. 2001: An annotated catalogue of fossil Ripiphoridae, taxonomic notes, and the description of a new genus and species from Baltic amber (Coleoptera: Ripiphoridae: Ripidiinae). Mitt. Geol. Paläontol. Inst. Univ. Hamburg 85: 165-195.

KLEBS R. 1910: Über Bernsteineinschlüsse in allgemeinen und die Coleopteren meiner Bernsteinsammlung. Schrift. Physikal.-Ökonom. Gesells. Königsberg 51: 217-242.

KUlicka R. \& SLIPINSKI S.A. 1996: A review of the Coleoptera inclusions in the Baltic amber. Pr. Muz. Ziemi 44: 5-11.

Lawrence J.F. \& Britton E.B. 1991: Chapter 35. Coleoptera (Beetles). In Mackerras I.M. (ed.): The insects of Australia. A Textbook for Students and Research Workers. Vol. 2. 2nd ed. CSIRO, Division of Entomology, Melbourne University Press, pp. 543-683.

Linsley E.G., Swain J.W. \& Smith R.F. 1952: The life history and development of Rhipiphorus smithi with notes on their phylogenetic significance. Univ. Calif. Publ. Entomol. 9: 291-314.

MeYer H.W. 2003: The Fossils of Florissant. Smithsonian Books, Washington, London, $258 \mathrm{pp}$.

Néraudeau D., Perrichot V., Dejax J., Masure E., Nel A., Philippe M., Moreau P., Guillocheau F. \& Guyot T. 2002: Un nouveau gisement à ambre insectifère et à végétaux (Albien terminal probable): Archingeay (Charente-Maritime, France). Geobios 35: 233-240.

RASNITSYN A.P. \& Ross A.J. 2000: A preliminary list of arthropod families present in the Burmese amber collection at the Natural History Museum, London. Bull. Nat. Hist. Mus. Lond. (Geol.) 56(1): 21-24.

RivNAY E. 1929: Revision of the Rhipiphoridae of North and Central America. Mem. Am. Entomol. Soc. 6: 1-67.

Ross A.J. \& York P.V. 2000: A list of type and figured specimens of insects and other inclusions in Burmese amber. Bull. Nat. Hist. Mus. Lond. (Geol.) 56(1): 11-20.

SCUDDER S.H. 1890: The fossil insects of North America (with notes on some European species). 2. The Tertiary insects. Report U. S. Geol. Surv. Terr. 13: 1-734.

SCUDDER S.H. 1900: Adephagous and clavicorn Coleoptera from the Tertiary deposit of Florissant, Colorado, with description of few other forms and a systematic list of the nonrhynchophorous Tertiary Coleoptera of North America. Mon. U. S. Geol. Surv., Washington 40: 148 pp.

Selander R.B. 1957: The systematic position of the genus Nephrites and the phylogenetic relationships of the higher groups of Rhipiphoridae (Coleoptera). Ann. Entomol. Soc. Am. 50: $88-103$.

Spahr U. von 1981: Systematischer Katalog der Bernstein- und Kopal-Käfer (Coleoptera). Stutt. Beitr. Naturk. (B) 80: 107 pp.

STEIN J.P.E. 1877: Drei merkwürdige Bernstein-Insekten. Mitt. Münch. Entomol. Ver. Ges. 1: 28-30.
Swanson J.R. \& Lewis S.E. 1993: Fossil insects of the Green River formation. Occas. Pap. Paleobiology St Cloud State Univ. 7(1): 1-9.

Waterlot G. \& Polvèche J. 1958: Carte géologique au 1/80000e: La Rochelle ${ }^{\circ} 152$ (2ème édition).

Wickнам H.F. 1920: Catalogue of the North American Coleoptera described as fossils. In Leng C.W. (ed.): Catalogue of the Coleoptera of America North of Mexico. Mt. Vernon, New York, pp. 347-365.

\section{APPENDIX - Commented list of fossil beetles attributed to the family Ripiphoridae}

Subfamily Pelecotominae:

Pelecotoma sp., Upper Eocene Baltic amber. Undescribed fossil, first citation in Klebs (1910). Spahr (1981) listed previous citations.

Subfamily Ripidiinae:

Ripidius megalophus Dalman, 1826. Upper Eocene Baltic amber. Original description in Dalman (1826). Spahr (1981) listed other citations.

Ripidius primordialis Stein, 1877. Upper Eocene Baltic amber. Original description in Stein (1877). Spahr (1981) listed other citations. Hieke \& Pietrzeniuk (1984) also listed three specimens attributed to this species.

Ripidius pyrrholophus Dalman, 1826. Upper Eocene Baltic amber. Original description in Dalman (1826). Spahr (1981) listed other citations.

Pauroripidius groehni Kaupp \& Nagel, 2001. Upper Eocene Baltic amber.

Subfamily Ripiphorinae:

Ripiphorus burmiticus (Cockerell, 1917) comb. n. in Albian Burmese amber (new datation by Cruickshank \& Ko, 2003). Originally described by Cockerell (1917) in the genus Myodites Latreille, 1819, junior synonym of Ripiphorus, listed in Spahr (1981), Ross \& York (2000) and Rasnitsyn \& Ross (2000). This fossil would need a revision. Cockerell (1917: 22) indicated that it has "five or six long processes" on its "flabellate antennae". After the photograph given by Ross \& York (2000: Fig. 12), it seems to have biflabellate antennae but a direct exam of the type specimen would be necessary to establish its exact relationships and generic attribution. It differs from Paleoripiphorus deploegi at least in its hind wing vein $\mathrm{M}$ basally sclerotized.

Ripiphorus sp. Upper Eocene Baltic amber. Undescribed fossil, Spahr (1981) listed previous citations.

Macrosiagon geikei (Scudder, 1890). Upper Eocene to Lower Oligocene, Florissant beds, Colorado, USA. Original description in Scudder (1890) and citation in Scudder (1900) in the genus Ripiphorus, but named Macrosiagon geikei by Wickham (1920). This fossil clearly needs a revision.

Kulicka \& Slipinski (1996) also listed several undescribed specimens of wedge-shaped beetles in various Baltic amber collections.

Swanson \& Lewis (1993) listed the presence of the family Ripiphoridae in the Eocene Green River Formation (USA) after Scudder but without further precision of date.

Received March 28, 2003; revised June 6, 2004; accepted September 26, 2004 